\title{
Entre filosofias e etnologias, uma conversa sobre Claude Lévi-Strauss Entrevista com Philippe Descola
}

\author{
L entrevistador: Edson Tosta Matarezio Filho \\ tradução: Morgane Alida Avery \\ REVISÃo: JULIANO BONAMigo
}

Dol 10.11606/issn.2316-9133.v24i24p349-367

Esta entrevista aconteceu no âmbito da produção do documentário $O$ que Lévi-Strauss deve aos Amerindios, ${ }^{1}$ lançado em 2013. O foco desse filme didático era não só reunir opinióes sobre conceitos difíceis do estruturalismo lévi-straussiano, mas também atingir esses conceitos pelo viés da influência indígena sobre Lévi-Strauss, o que tornava o desafio mais interessante. Encontrei-me com o professor Philippe Descola numa agradável manhã de 2012, em uma passagem sua pelo Rio de Janeiro.

O foco de nossa conversa foi a obra do mestre francês e sua importância para os estudos americanistas. Dessa maneira, o leitor poderá acompanhar uma apreciaçáo de Descola sobre as influências que levaram Lévi-Strauss a aproximar-se da etnologia, com um destaque para alguns autores que o influenciaram e os grupos indígenas pelos quais passou nos anos em que morou no Brasil. A entrevista segue para um exame de alguns termos-chave do estruturalismo lévi-straussiano, como: estrutura, natureza e cultura, dualismo, transformação, dentre outros. O leitor deve ter em mente também que o entrevistado muitas vezes faz comentários menos relacionados à questão proposta e mais atinentes à concepção do documentário para o qual estava sendo filmado.

A admiração por seu orientador fica evidente em muitos momentos, mas náo deixamos de notá-la quando Descola avança por rotas inexploradas por Lévi-Strauss. Como no trecho, "no fundo, Lévi-Strauss diz que os não humanos, as plantas e os animais, são bons para pensar. Claro, mas o que eu via nos Achuar eram plantas e animais que são parceiros sociais, com os quais se pode fazer guerra”. Uma crítica apoiada numa rigorosa investigação de campo, mesma fonte da qual surgiu toda uma etnologia herdeira de Lévi-Strauss e que renovou os estudos sobre os ameríndios.

Descola viveu entre 1976 e 1979 junto ao povo Jivaro Achuar, do Equador. Desse período de campo, extraiu o material para a escrita de 
sua tese de doutorado, defendida em 1983 na École Pratique des Hautes Études (EPHE), sob orientação de Lévi-Strauss. O resultado desse trabalho pode ser conferido em La Nature domestique. Symbolisme et praxis dans l'écologie des Achuar (1986). Desde então, ocupou os principais postos para um antropólogo francês. Tornou-se mestre de conferências e diretor de estudos na École des Hautes Études en Sciences Sociales (EHESS - Paris). Em 2000, foi indicado como professor da cadeira de Antropologia da Natureza, no Collège de France. No ano seguinte, torna-se diretor do Laboratoire d'anthropologie sociale (Collège de France/CNRS/EHESS), mesmo cargo ocupado por Claude Lévi-Strauss.

A obra de Lévi-Strauss representou um grande avanço para os "estudos amerindios", como era o americanismo antes desse autor?

PD: Depende do que se entende por "estudos ameríndios", se entendemos os estudos sobre as sociedades ameríndias das duas Américas, Lévi-Strauss sempre falou - e com razão - que a massa de informação etnográfica acumulada sobre os índios da América do Norte, pelo Bureau of American Ethnology em particular, era considerável, e representava uma contribuição muito importante para o conhecimento da Humanidade. E ele mesmo utilizou muito esses documentos, sobretudo nas Mitológicas, mas não só. $\mathrm{E}$, além disso, ele tinha uma admiração muito grande por um grande americanista que era Franz Boas, no qual admirava a capacidade para fazer sínteses etnográficas de grande qualidade sobre populações pelas quais ele mesmo se interessou. Ao passo que a situação dos índios da América do Sul é um pouco diferente.

É verdade que quando Lévi-Strauss foi para o campo havia os grandes etnógrafos como [Karl] Von den Steinen, [Theodor] Koch-Grünberg, [Konrad Theodor] Preuss, os quais eram essencialmente alemães. A etnografia da Amazônia, até os anos 1920, era uma etnografia alemã - [Curt] Nimuendajú, claro - e é uma literatura que Lévi-Strauss conhecia um pouco, ainda que ele não falasse alemão. Von Den Steinen, em particular, desempenhou um papel importante para ele e, a propósito, tenho o livro de Von Den Steinen que ganhei de Lévi-Strauss quando ocupei a cátedra no Collège de France e que era um livro que ele havia ganhado de [Alfred] Métraux. De certa forma, tem um tipo de transmissão do saber e dos objetos-fetiche que passou por este livro de Von Den Steinen, Através do Brasil central.

Lévi-Strauss não revolucionou a etnografia americanista imediatamente, só nos damos conta disso mais tarde. E durante muito tempo - incluindo os americanistas - não tínhamos verdadeiramente consciência de que Lévi-Strauss era um etnólogo americanista. Claro, havia escrito sobre os Bororo, até havia escrito artigos muito técnicos: esse artigo no Journal de la Société des Américanistes sobre os estojos penianos e sobre os sistemas de 
emplumagem das flechas nos Bororo é um artigo de etnografia extremamente minucioso (LÉVI-STRAUSS, 1936). Tinha uma obra de etnógrafo americanista, mas que demorou muito para exercer uma influência para além de um círculo muito restrito de pessoas que se interessavam por populaçóes do Brasil Central. Então a questão da relação entre sua obra e o pensamento ameríndio ou a etnologia ameríndia é complicada.

O senhor afirmou certa vez que "o estruturalismo funciona' bem na Amazônia, pois os indigenas parecem espontaneamente estruturalistas". Poderiamos pensar o inverso também, em que medida o pensamento de Lévi-Strauss é amerindio?

Lembro muito bem que, faz alguns anos, quando Anne-Christine Taylor e eu havíamos editado um volume da revista L'Homme intitulado "La remontée de l'Amazonie" (DESCOLA; TAYLOR, 1993), e que tinha como objetivo fazer um mapeamento dos estudos etnológicos e etno-históricos sobre a Amazônia, havíamos escrito no prefácio da introdução ao volume que uma das razóes pelas quais Lévi-Strauss era estruturalista era que havia encontrado entre os ameríndios gente espontaneamente estruturalista. Alguns dias depois da sua publicação - ou antes, porque havíamos lhe instado a entregar o manuscrito - no laboratório ele me falou: "Aí você exagera". Quando perguntei por que, ele respondeu: "O que eu faço vai bem além do mundo ameríndio". E é verdade. Então, pode-se dizer que certas intuiçôes fundamentais na sua obra, na sua maneira de perceber as coisas, são oriundas provavelmente do campo etnográfico.

Quando chegou em Sáo Paulo - tal como ele diz na sua entrevista para Didier Eribon - os brasileiros estavam surpresos com o que ele ensinava porque o que eles queriam, quando convidaram Lévi-Strauss para a Universidade de Sáo Paulo, era um durkheimiano. E ele não era muito durkheimiano. Na época ele era antes marxista, de fato. E a "boa sociedade" paulista achou que era um pouco exagerado. Então, a bem dizer, sua formação teórica era muito eclética naquela época. Entre os Bororo ele encontrou a intuiçáo de que a vida social é feita de trocas. Um sistema de metades pelo qual toda a vida de um indivíduo está determinada e se torna possível graças à outra metade. Assim, quando ele chega no Brasil, ele não tem ainda uma concepção teórica muito claramente formulada e sua influência intelectual é antes o marxismo. Enfim, ele conhece bem, de fato, uma variedade do marxismo que não é o marxismo tal como o conhecemos hoje em dia. Ele conhece bem o jovem Marx em particular, e o que lhe surpreende durante sua estadia entre os Bororo é a questáo da troca e da reciprocidade. É por isso que essa noção tem tal papel na sua obra posteriormente, notadamente n'As estruturas elementares do parentesco. De certa maneira, o modelo d'As estruturas elementares do parentesco que se 
desenvolve a partir da reciprocidade, por complexificação progressiva dos sistemas de trocas de matrimônio, é o modelo elementar puro das duas metades Bororo, nas quais tudo o que diz respeito à vida de um indivíduo é assumido pelo papel da outra metade, desde o nascimento até a morte. O que ele descobre - ele era um leitor de Rousseau - na vida social de uma sociedade concreta é uma maneira de criar elos extremamente fortes, extremamente potentes entre segmentos que náo tinha experimentado antes. Isso foi um elemento que teve um papel central na sua obra.

Entretanto, eu diria que ele se torna verdadeiramente americanista depois. Quando ele voltou do Brasil, ele conhecia os Bororo, os Nambiquara, os Guaycuru, havia acumulado muitas informações etnográficas esparsas, alguns objetos, mas não tinha uma teoria particular das sociedades ameríndias. Isso tudo se estabelece nos Estados Unidos, quando, durante a guerra, ele ensina na New School For Social Research e aí descobre essa literatura etnográfica sobre os ameríndios da América do Norte, da qual falarei depois. Também conhece os grandes autores. Boas, o primeiro, que ele não tinha lido anteriormente. E é nas discussōes com Jakobson, em Nova Iorque, que progressivamente se constrói o que virá a ser o estruturalismo.

Penso que o que os etnólogos americanistas, em particular os especialistas da Amazônia, retêm de Lévi-Strauss é talvez menos o Lévi-Strauss, dentre outros, da "Organização social" (1936), ou de "As organizaçôes dualistas existem?" (1958) - o qual é um artigo de grande virtuosidade -, do que tudo o que diz respeito, por um lado, à sua análise da mitologia e, por outro, às dificuldades que ele também passou para falar da magia e do xamanismo. No seu artigo sobre a eficácia simbólica, por exemplo, sente-se que é um domínio sobre o qual - quando ele faz o paralelo entre a cura xamanística e o tratamento psicanalítico - ele não tem uma fundamentação muito sólida. É verdadeiramente nas Mitológicas que ele destaca traços próprios ao mundo ameríndio. É um pouco um paradoxo, porque ele sempre falou que as Mitológicas náo eram um conjunto de livros consagrado aos ameríndios em particular, mas a uma forma particular de pensar que era o pensamento mítico. Mas acontece que, essencialmente, os mitos dos quais ele se serve sáo oriundos da América do Sul e da América do Norte, e muito pouco de outras regiōes do mundo. E é aí, penso eu, que sua contribuição de americanista é mais manifesta, apesar do fato de sua documentação ser frequentemente datada. No fundo o grande desenvolvimento dos estudos etnográficos e etnológicos sobre a Amazônia começou nos anos 1960-1970. Assim, ele serve-se muito de Capistrano de Abreu, de Nimuendajú, de tais autores que são autores estimáveis, mas em comparaçáo com a qualidade da informaçáo etnográfica da qual dispomos agora, aquela era muito diferente. 
E apesar dessa documentação um pouco datada, ele salienta coisas muito importantes: a dialética do contínuo e do discreto, por exemplo, que são temáticas que ele reparou nos mitos e das quais os etnólogos que trabalharam posteriormente na Amazônia perceberam logo a pertinência para as sociedades particulares que eles estudavam.

Tem algo efetivamente que sempre me surpreendeu e do qual aliás falei com ele. Nas Mitológicas ele se serve como que de uma ferramenta classificatória - para dar uma ordem a matrizes contrastivas de mitemas -, de uma oposiçáo entre Natureza e Cultura, tais como o cru e o cozido. Tal oposição - é o que eu tento mostrar na minha obra - não é muito pertinente nessas sociedades, nem em muitas outras regiōes do mundo. E contudo, apesar desse uso da oposição entre Natureza e Cultura, do qual se pode pensar que corresponde a algo que não existe realmente nessas sociedades, ele pôs em evidência contrastes, já que é isso que conta. Esses contrastes, os subsumo sob duas grandes categorias de Natureza e Cultura, mas tais contrastes estão aí, são mais complexos, mais complicados, são contrastes de igualdade.

$\mathrm{O}$ que ele fez nas Mitológicas foi perseguir este grande percurso que havia começado n' $O$ pensamento selvagem e que consiste em compreender uma lógica das qualidades sensíveis, uma lógica das "qualidades secundárias", como se diz na filosofia. Quer dizer, das qualidades que são subjetivamente definidas e apreendidas e que constituem um elemento extremamente importante de conhecimento do mundo para um grande número de sociedades no mundo. Ele concentrou esse esforço sobre o mundo ameríndio. Assim que, nesse sentido, mas tardiamente, se podemos dizer, e na sua própria carreira, e no efeito que ele teve, ele é também um americanista.

Outra coisa que também é interessante é que nos últimos anos da sua vida, algo realmente lhe interessava muito: era a Amazônia e particularmente o Brasil, e ele gostava muito de falar e de ler, evidentemente, toda a literatura etnológica sobre a Amazônia. Lia muito sistematicamente tudo o que se lhe enviava, às vezes para a grande surpresa de jovens colegas brasileiros. Lembro que Aparecida Vilaça, que havia pedido para encontrar-lhe, surpreendeu-se muito em ver que ele havia lido os textos que ela lhe tinha enviado. Recebia com muito prazer os visitantes brasileiros também, e assim via-se que no fim da sua vida essa dimensão afetiva para com os povos ameríndios e aqueles que lhes estudavam levava a melhor - "a melhor" entendemos subjetivamente - sobre o grande projeto de construção de uma teoria antropológica capaz de tratar de qualquer fato social e cultural no mundo.

Portanto, era e náo era ao mesmo tempo um americanista, como todos os antropólogos cuja ambição ultrapassa a zona etnográfica que estava na origem do seu interesse pela etnologia. Paralelamente, se pode dizer que 
muitos dos problemas que ele se colocou, na parte mais ampla do seu trabalho de antropólogo, são questóes que nasceram da sua experiência etnográfica no Brasil. Isso se percebe muito nitidamente em Tristes trópicos, como é um livro retrospectivo, um livro de biografia intelectual, se vê muito bem, na maneira pela qual ele fala dos Bororo e dos Nambiquara, que há dois modelos intelectuais do que no fundo é uma sociedade.

Acho que a maioria dos antropólogos também tem isso em mente, um tipo de modelo implícito do que é a vida social. É por um lado a reciprocidade e por outro uma espécie de átomo, de entre-si. Como definir isso? Um tipo de mônada pura que era esse pequeno grupo [os Nambiquara], naquela época já errante, mas que, contudo, suscitou a sua afeição, é preciso dizê-lo.

Também há a formação. Acho que é preciso insistir sobre um aspecto a respeito de Lévi-Strauss, mas também de muitos americanistas, que é que antes mesmo da etnologia surgir, já existia uma literatura sobre os índios e, assim, a etnologia americanista está precedida por uma reflexão filosófica sobre os ameríndios. Tem-se Montaigne, obviamente. Tem-se a versão positiva e a versão negativa, tem-se Rousseau, mas também Chateaubriand, e particularmente nas Memórias de Ultratumba, onde ele fala, a propósito dos índios da América do Norte, dos "povos da solidão". Tem algo de muito justo nessa definiçáo. Por que os "povos da solidão"? Primeiro porque, como falou Lévi-Strauss, ele sempre preferiu os trópicos vazios aos trópicos superlotados. Sabemos bem que os trópicos vazios estáo vazios porque foram esvaziados, cabe dizer, pelo choque epidemiológico. Os trópicos americanos não foram sempre vazios, todavia - foi o caso durante vários séculos a partir dos séculos XVIII e XIX - são populaçóes que se encontraram, em número muito pequeno, mergulhadas num espaço imenso onde as relaçóes que sustentavam com os humanos do seu entorno eram no mínimo tão importantes quanto as relações que sustentavam com não humanos. Isso é algo muito importante.

Penso que, na obra de Lévi-Strauss, a relação dominante entre Natureza e Cultura vem do fato de que para as populaçóes amazônicas, desde que se sai de uma casa se está num universo onde os humanos são escassos, mas onde os não humanos são abundantes, e onde a vida social ultrapassa em muito a vida social com os humanos, por abranger o restante dos existentes. Lévi-Strauss percebeu isso muito bem. Não o formulou de tal maneira, mas foi bem percebido e é também isso que alimenta o seu interesse pela relação entre Natureza e Cultura que está presente n'O pensamento selvagem e que logo virou o tema principal das Mitológicas. A Amazônia, eu penso, é talvez uma regiáo que, mais do que outras, permitia alimentar essa reflexáo sobre o elo com o entorno.

Você perguntava-me sobre a relaçáo entre Lévi-Strauss e o pensamento indígena. Acho que é preciso desconfiar ao empregar expressóes tais como "o pensamento indígena". Sabe, quando eu era novo, interessava-me tan- 
to pelas Terras Baixas como pelas Terras Altas, quer dizer, pelo Mundo Andino. Se constituiu naquela época, tanto por meio de pesquisadores peruanos, bolivianos em menor grau, e equatorianos, como por meio de europeus e americanos que os estudavam, um tipo de constelação do "Homem Andino", do "Pensamento Andino", Lo Andino, como dizia-se então, que fossilizou sob uma forma, um conjunto de traços característicos, uma área cultural. Entâo falar de "Pensamento Indígena" é perigoso porque, precisamente, Lévi-Strauss era muito cauteloso ao empregá-lo - ele empregava essas expressóes -, porque era simplesmente para designar uma forma particular numa regiáo do mundo, de um pensamento não domesticado, se assim se pode dizer, tal como o "Pensamento Selvagem". Não é alguma coisa que viraria um tipo de filosofia indígena com características particulares do tipo que poderíamos comparar à filosofia grega ou à filosofia racionalista inglesa etc. Porque se pode dizer, por exemplo - e é a fonte das Mitológicas -, que, quando Lévi-Strauss considera os mitos das duas Américas, ele considera implicitamente um grupo de transformação.

O "Pensamento Indígena", quando é panamericano, não é mais da amazônia do que dos índios do Chaco, ou dos índios dos planaltos ou até da costa do noroeste. Tem realmente um conjunto muito amplo que decorre do fato de que as Américas se desenvolveram isoladamente - um pouco como a Austrália - durante milênios e milênios, com movimentos de ideias, bens e pessoas, e esse conjunto acabou por constituir-se num verdadeiro grupo de transformação - é verdade! - cujas variantes se pode observar em regiōes muito distantes umas das outras. Caso se possa falar de um "Pensamento Indígena", penso que se deveria falar nesse sentido, quer dizer: na escala das Américas, mais do que na escala de uma área etnográfica como a Amazônia.

Muitas questôes que eu tinha em mente o senhor já passou por elas. Gostaria de continuar ainda na questão das Mitológicas. Elas são uma grande virada no tipo de análise que era feita dos mitos, da América do Sul principalmente. Lévi-Strauss tem esse mérito de definir os grandes temas, os grandes motivos da mitologia amerindia.

PD: Sim. Mas é só porque ele deu uma amplitude táo monumental ao estudo das mitologias ameríndias nos quatro volumes das Mitológicas, que só se pode ficar tomado pela admiraçáo por essa espécie de monumento extraordinário aos ameríndios. Mas as primeiras tentativas de análise estrutural das mitologias ameríndias partem de mitos da América do Norte. É a "A gesta de Asdiwal" (1973), por exemplo, que é o modelo da análise dos mitos segundo um grupo de transformação. Uma vez mais, e Lévi-Strauss deste ponto de vista era bem claro, náo se deve considerar que é um livro consagrado ao pensamento amazônico indígena, seria extremadamente redutor dizer isso. 
É verdade que esta análise dos mitos que ele propôs tinha algo de inteiramente novo. Mas uma vez mais, as primeiras tentativas que ele fez de análises de mitos segundo o método estrutural abrangiam antes mitos da América do Norte e a grande novidade era de não tomar os mitos - é, enfim, a oposição clássica entre sintagmática e paradigmática - segundo seu conteúdo interno, mas de os modelizar de maneira a tornar possível a junçáo de um elemento de um mito com um elemento de outro mito de alhures que transforma o primeiro elemento. Se quisesse fazer das Mitológicas uma maneira nova de abordar os mitos sul-americanos, não teria se incomodado em realizar imensas distâncias: de ir procurando um mito no norte da América do Norte para transformar um mitema da América do Sul. E isso é muito importante. É um deslocamento da Amazônia para o interior do grande campo da mitologia ameríndia panamericana.

Gostaria que você falasse sobre uma espécie de anulação do próprio sujeito de Lévi-Strauss sobre a qual ele comenta em entrevistas e em alguns textos. Podemos pensar essa anulação como uma espécie de método antropológico por excelência? Ao mesmo tempo que ele se anula como sujeito, como individuo, ele preenche essa lacuna com outro pensamento, e o faz dialogar com o racionalismo europeu...

PD: Sim, essa ideia de que os mitos se pensam através dele, que ele não é nada senão um instrumento de conexão, em suma, entre mitos que de outra forma náo teriam concretamente os meios de troca entre si.

É verdade e, ao mesmo tempo, eu diria que há um pouco de falsa modéstia nisso tudo. Porque tem nas Mitológicas um trabalho da intuição e da memória que é propriamente sobre-humano. Primeiro, mal se vê como isso poderia ser reproduzido, pois é algo muito idiossincrático, já que o encaminhamento da transformação, digamos, é sempre diferente. A terra dos mitos é redonda, mas jamais se segue o mesmo caminho. De modo que, essa via de transformação que Lévi-Strauss seguiu de mitema em mitema, nas Américas, poderíamos fazê-la seguindo outro caminho, se tivéssemos o mesmo gênio que ele - mas não vejo quem poderia fazê-lo. Mas isso supóe talentos prodigiosos, e talentos, uma vez mais, sobre-humanos. Quer dizer, primeiramente uma memória extraordinária. Lévi-Strauss tinha fichas, mas não são simplesmente as fichas, precisa-se ter em mente milhares de mitos, milhares de episódios, e ser capaz, num certo momento, de dizer: "Veja, aquele parece ser a versão, por exemplo, de tal mitema a uns dez mil quilômetros dali". E depois pode-se verificar as fichas, mas deve-se ter tudo isso em mente e, sobretudo, essa capacidade de inferir tipos de qualidades num mitema. Esse também é um talento de tipo particular: de ver que o que importa aqui é a chave astronômica, ou a chave técnica etc. Ou seja, que o que importa aqui é a forma do tronco de uma árvore e ali as proprie- 
dades neurolépticas de uma planta, ou o comportamento animal etc.: isso também é preciso saber. Obviamente, isso ele confirmará nas enciclopédias etc. Mas ele sabe muito...

Assim, tem essa mobilização de um saber absolutamente considerável que faz com que, enquanto Ricoeur dizia que o estruturalismo é "o kantismo sem sujeito transcendental”, haja no fundo um sujeito transcendental aí: é essa espécie de herói do pensamento que consegue combinar massas de informação, massas de saber, de maneira a tecer, a avançar nesses caminhos interpretativos, de transformação etc.

Portanto, acho que há um pouco uma questão de vaidade na ideia de que os mitos se pensam através dele assim, sozinhos. Também se pode entender o que ele quer dizer: que se estes mitos fossem transformados uns nos outros, um sujeito humano dotado de grandes capacidades também seria capaz de reencontrar as suas transformaçóes. Ou seja, que substitui aquilo que talvez um Tikuna poderia entender do que um Tlingit lhe diz trocando ou discutindo sobre suas mitologias, ou até mesmo sobre as possibilidades de transformação de uma na outra. Hoje se tornou mais clássico: situaçôes nas quais um Tikuna poderia encontrar um Tlingit tornaram-se comuns, mas durante muito tempo náo foi o caso. E assim se precisa desse intermediário intelectual, alguém que faz ramificações de uma grande complexidade entre todas essas mitologias. E para isso precisa-se de uma inteligência excepcional. Portanto, os mitos pensam-se através dele, mas pensam-se através de uma mente excepcional também.

Bom, talvez principalmente através desse pensamento que ele extrai, dessa sintese...

PD: Não é uma síntese no sentido clássico. Ele chega em sínteses parciais sobre certas coisas, sobre relaçôes entre venenos de caça, a cheia dos rios, isso tudo. São sínteses parciais que nesse sentido são interessantes para nós, os etnólogos que estudam a Amazônia, porque de fato são pistas das quais verificamos a pertinência em certos campos de prática que não são necessariamente os mesmos que aqueles que Lévi-Strauss convocou para a análise do mito. Mas eu não definiria as Mitológicas como uma síntese, seria depreciar, de certa forma, o trabalho que ele conduziu. Ao contrário, o que é extraordinário é que é uma analítica, até mesmo o inverso de uma síntese. É uma analítica geral de certa forma de pensamento e de perceber as qualidades no mundo que ocorre de maneira bastante consistente nas Américas. Portanto, não é uma síntese.

Não é uma sintese, mas ele transforma aquilo numa massa de dados, num conjunto que dialoga no mesmo nivel, de igual para igual, com todo o pensamento ocidental, filosófico, cientifico, de certa forma. 
PD: Sim, mas isso ele havia começado antes. Isso é uma demonstração, se podemos dizer, mas o projeto estava presente n' $O$ pensamento selvagem. N'O pensamento selvagem tem certa forma de pensamento das qualidades secundárias, digamos, da lógica do concreto que se encontra nas populaçôes autóctones e no pensamento ocidental também, e que traz na sua complexidade muitas coisas. Portanto, é um projeto antigo dele, e que toma, evidentemente, dimensóes consideráveis.

Acontece, às vezes, de ele comparar o pensamento autóctone com o pensamento ocidental, mas ele teve cada vez mais, ao longo do tempo, um rechaço pela filosofia ocidental que ele considerou cada vez menos interessante. Com exceção obviamente de certas personalidades filosóficas das quais ele foi próximo, como Merleau-Ponty, e sem falar das suas relaçóes conflituosas com Sartre ou com Ricoeur, com Lévinas, das quais fala muito pouco, ele não tem nenhuma afinidade com a filosofia analítica. É evidente que se falas obretudo da filosofia continental, que no fundo não lhe interessa realmente. Desse ponto de vista, há um efeito pedagógico e polêmico. E ele diz: "Bom, sim, são pensamentos equivalentes, mas o nosso é, finalmente, menos interessante que o seu". Eis o que ele pensa, sem, no entanto, menosprezar - pelo que foi, às vezes, censurado - as grandes realizaçôes do pensamento ocidental, mas que lhe interessam mais no domínio da arte e da literatura, da pintura e da música que no da filosofia, o que é curioso para um filósofo de formação. Mas acho que é um movimento clássico. Deve-se pensar que na França há esse movimento muito antigo, que remonta pelo menos até Durkheim, pelo qual filósofos abandonam a filosofia para fazer ciência social, antropologia, sociologia, e que supóe uma relação muito particular, retrospectiva, com a filosofia. Ou seja - penso que eu também estou neste caso -, todos passamos por este mesmo movimento: ao mesmo tempo a filosofia conduziu-nos a colocar para nós mesmos, sob certa forma, certo tipo de perguntas e, portanto, perguntas que não se colocam necessariamente outros cientistas ou outros cidadãos do mundo, e a tentar reformular essas perguntas de maneira a fazê-las escapar à problemática filosófica da filosofia tradicional.

Portanto, há essa espécie de relação complicada entre filosofia e antropologia que é característica do pensamento francês e que se encontra em Durkheim, em Mauss, que se vê obviamente em Lévi-Strauss. Mas também em Bourdieu e em todos aqueles praticantes franceses das ciências sociais, que ao mesmo tempo dispóem de uma cultura filosófica e procuram ultrapassar a filosofia. Isso tudo fazendo talvez também filosofia de outra maneira. É, acho eu, o caso de Lévi-Strauss.

No debate entre Lévi-Strauss e Ricoeur, este diz num certo momento: "Mas, no fundo, você tem um pensamento científico". É obvio que ele tem um pensamento cientifico! Eis a diferença entre Lévi-Strauss e Ricoeur. 
Lévi-Strauss admitiu que seu projeto é um projeto científico e não filosófico. Há um matrimônio, um companheirismo com a filosofia, mas o seu projeto é de produzir conhecimentos sobre fatos, sobre maneiras relativamente enigmáticas de pensar. É por isso que se precisa proceder de maneira científica, deve-se acumular dados e atracar-se com eles para fazê-los dar razão. É bastante diferente do percurso filosófico clássico, ainda que os filósofos, especialmente os filósofos das ciências, também se interessem pela empiria.

Eis aqui a diferença. Os praticantes das ciências sociais, dos quais Lévi-Strauss é na França a encarnação, são pessoas que têm essa curiosidade filosófica, mas que decidem tratá-la de maneira científica, quer dizer, impondo-se ao mesmo tempo a consideração de certo tipo de dados e formas de raciocínio que não é necessariamente aquele dos filósofos.

Como você comentou em outra entrevista, também o fato de ele ter fundado um laboratório [Philippe: Absolutamente], isso marca também a proposta de uma investigação científica.

PD: Quando Lévi-Strauss criou o Laboratório de Antropologia Social, subscreveu-o à Nature, ${ }^{2}$ o que era inconcebível naquela época. Imagine, nos anos 1960, primeiro fazer um laboratório de antropologia - escolher o termo "laboratório" - e ainda que tivéssemos Nature para informar-nos permanentemente do que se fazia nas outras ciências. Lévi-Strauss é um materialista convicto, e uma maneira de ser materialista - o disse várias vezes - é de encontrar no funcionamento do Pensamento Selvagem - prefiro "Pensamento Selvagem" à "Pensamento Indígena" - formas de pensar, ou melhor, conexões entre coisas que cientistas que trabalham na química ou na física descobrem de outra forma. Eis verdadeiramente um estado de espirito científico.

Voltando um pouco aos ameríndios, numa perspectiva da obra lévi-straussiana como um todo, partindo até mesmo dos textos anteriores à Estruturas elementares do parentesco, passando pelas Estruturas, O totemismo hoje, O pensamento selvagem, Mitológicas... Essa trajetória poderia ser pensada como uma progressiva "amerindianizaçâa" desse pensamento? E pensando nas três "amantes" de Lévi-Strauss, o marxismo, a geologia e a psicanálise; os estudos sobre os amerindios seriam uma espécie de quarta amante nessa combinação de reflexóes, métodos e teorias?

PD: Sim, acho que é uma amante, ou maîtresse secrète, de fato, foi em todo caso o que suscitou nele o prazer de pensar. Como dizia acima, o que ele descobre quando chega ao Brasil - e se encontra entre os Bororo, entre os Nambiquara -, são formas sociais sobre as quais havia lido textos, mas que jamais havia observado ou compartilhado. E penso que é uma experiência que fazemos todos nós enquanto etnólogos. Quer dizer que, 
no fundo, a grande surpresa que temos é que, quando lemos os textos, dizemos, "A gente, os fulanos fazem isso, fazem aquilo, casam assim, pensam assim etc...". É muito abstrato. Logo, repentinamente, compartilhamos a vida das pessoas que vivem segundo formas de vida completamente diferentes das nossas e essas experiências de vida são tão belas como experiências de pensamento filosófico, precisamente.

Falar de uma amerindianização progressiva da sua obra, podemos dizê-lo, se quisermos. Mas eu acho que o que acontece na sua obra é um interesse, cada vez mais, marcado pelo pensamento. Começa com problemáticas que são muito características dos seus interesses sociológicos iniciais, mas embora sejam questôes de organização social, são questôes de organização social fundadas - isso é muito claro n' As estruturas elementares do parentesco - sobre tipos de imperativos categóricos do pensamento. As estruturas elementares do parentesco é a exigência da regra, é a dádiva, como meio de sintetizar o Eu e o Outrem, são verdadeiramente imperativos categóricos.

De modo que há algo no pensamento que permite o exercício de tais instituiçóes sociais. E, progressivamente, diz: "Vamos ver realmente o que acontece no pensamento quando o pensamento mesmo, em vez de pensar coisas, pensa-se a si mesmo pensando as coisas". E é um pouco assim que ele vê os mitos. $\mathrm{E}$ assim ele mesmo se pensa como alguém que pensa o pensamento quando se pensa ele mesmo pensando coisas. Sáo movimentos de reflexividade numa escala dois ou três, e acontece que, fascinado pelo pensamento ameríndio, foi este que lhe serviu de objeto.

Por que ele interessou-se pelo pensamento ameríndio e pelas instituiçóes ameríndias, em vez de, por exemplo, pelas sociedades africanas ou pelas sociedades da Ásia? Porque as coisas se dáo para ver de maneira menos imediata e literal. No fundo, é dentre as três amantes - há de fato três amantes, a psicanálise, a geologia e Marx - que ele percebe, nos três casos, que os fundamentos da vida social são inconscientes. E talvez ele apostou - enfim, disso estou seguro porque o falou de uma maneira ou de outra - que era mais interessante entender as redes inconscientes da vida social do que se fazer bombardear por modelos locais. É a diferença entre modelos locais e modelos inconscientes que constituiu a famosa polémica com Maybury-Lewis.

$\mathrm{Na}$ África são muito bons com os modelos locais: teorias complexas da pessoa, da organização social, da organização segmentar, e é a mesma coisa na Ásia. O que o atraiu nas Américas era isto, é que se tinha menos modelo local, e, aliás, quando um modelo é local, ele o desfaz, como é o caso das sociedades dualistas. Os Gê são uma sociedade dualista? Não, de modo algum! Esse é um modelo local, mas na realidade é um sistema ternário. E penso também que é o que nos atrai, foi o que me atraiu, e acho que há muitos americanistas nessa mesma situação. "Por que fui trabalhar na 
Amazônia e não na África?” Por isso, porque são sociedades onde o socius parece indefinível, onde ele não tem contorno, são sociedades, sem fé, sem lei, sem rei, para retomar a velha fórmula. E isso é muito excitante intelectualmente, é um desafio. Então é assim, acho que podemos ver o que você chama de amerindianização do seu pensamento.

Pensando agora nas teorias mais contemporâneas, principalmente nas suas elaboraçóes e nas de Eduardo Viveiros de Castro. Eu queria que o senhor comentasse sobre o quanto seus escritos sobre o animismo, e mesmo sobre os Jivaro, e os escritos do Eduardo sobre o perspectivismo são duas elaboraçóes, duas teorias, tributárias dessa herança lévi-staussiana.

PD: É evidente, são diferentes maneiras. Lembro-me de ter caminhado ao longo desta praia com Eduardo faz muito tempo, discutindo assim, durante horas. No começo, para mim em todo caso - deixo Eduardo responder ele mesmo sobre tais questóes -, minha maneira de ver as coisas era mais bem uma insatisfação frente à maneira pela qual Lévi-Strauss tratava questôes que havia descoberto no campo. Quando Lévi-Strauss diz "os não humanos, as plantas e os animais são bons para pensar...", é obvio. Mas o que eu via com os Achuar, eram plantas e animais que náo só eram bons para pensar, mas também eram bons como parceiros sociais, de um tipo ou outro, com os quais até se pode guerrear, aliás — enfim, pouco importa. E aí, não encontrava muita coisa em Lévi-Strauss. Portanto, fiz todo um desvio antes, não de "voltar", porque é uma influência evidente e profunda demais em todos nós, mas tive que fazer um leve deslocamento no começo. Porque tem em Lévi-Strauss uma desconfiança a respeito da análise dos rituais, embora fale deles em "O feiticeiro e sua magia" e em "A eficácia simbólica”, interessa-se mais para o pensamento que se vira para si mesmo enquanto pensa o mundo, como falava acima. $\mathrm{O}$ ritual deixa-o inconfortável.

Ora, o que nossa geração, Eduardo, eu e outros, encontramos no campo, eram também sociedades que ou tinham uma vida de rituais então muito elaborados, como pode ser o caso no Brasil Central, ou, como no caso Jivaro, muito pouco elaborados, mas que, não obstante, eram uma forma constante de mediação com o seu ambiente social e não humano.

Era um aspecto que Lévi-Strauss chama mitologia implícita: a mitologia explícita está nos mitos, mas a mitologia implícita é o que surge, que transparece na vida ritual, nas interaçóes que se mantêm no entorno. Foi algo que ele sempre deixou de lado.

Assim, o meu desafio, de certa forma, quando voltei do campo, foi de entender isso a respeito dos Achuar e, de maneira mais geral, da Amazônia, da mesma forma que o Eduardo fez para o canibalismo. Eis onde nos encontramos, ele partindo do canibalismo Araweté e do canibalismo Tupi, e 
eu partindo da relação às plantas e aos animais, e talvez por isso conseguimos avançar um pouco os estudos amazônicos, e naquele momento reencontramos as Mitológicas. Mas acho que foi preciso afastar-se um pouco no começo de uma abordagem que considerava em primeiro lugar a mitologia explícita e dava menos importância à mitologia implícita, para reencontrar depois a mitologia explícita e reparar quais eram os elos entre as duas.

Eu queria saber também com relação aos limites disso, no fim das contas seria o limite da própria antropologia. O limite de um pensamento social de uma sociedade ser traduzivel no de outra. O quanto Lévi-Strauss avança nisso e o quanto existem limites para isso...

PD: Os limites da abordagem antropológica?

Principalmente pensando na ideia de tradução, na ideia de transpor um pensamento para o outro. A ideia de explicação antropológica também.

PD: Acho que se deve distinguir vários níveis. Primeiro tem esta incrível fecundidade na abordagem etnológica e etnográfica do vaivém - e sempre através de um observador, é claro - entre a cultura do observador e a cultura do observado. E é esse tipo de ajuste de tentativas de traduçáo, qualquer que seja o termo que se queira dar, que é extremamente fecundo porque implica movimentos de retorno, evidentemente, sobre o pensamento do observador, sobre a sua própria sociedade etc. É um aspecto muito fecundo da etnologia que repararam, aliás, observadores exteriores, tais como filósofos...

E, além disso, tem outro aspecto mais geral, pode-se dizer francamente: a antropologia é a forma científica de uma empreitada pouco comum na história da humanidade, de fazer uma teoria da natureza humana apoiada em dados. E se a antropologia é herdeira dessa ambição, ela vai em parte utilizar como instrumentos aqueles que foram objetivados na história dessa tradição mesma. Daí a grande dificuldade - assim é como eu a percebo e é aquela que tento superar - de elaborar ferramentas intelectuais que sejam suficientemente desconectadas dessa tradição histórica, pelo meio das quais nós mesmos, na Europa e depois no mundo ocidental, objetivamo-nos de maneira a poder compreender sociedades, filiaçóes, culturas, povos que se desenvolveram em outras circunstâncias históricas.

E aí penso que tem, provavelmente, uma diferença nas abordagens da antropologia. Ou seja, isso supõe que admitamos não a superioridade da abordagem científica, mas que é muito difícil escapar de certo tipo de formulação dos problemas, ainda que mudemos os conceitos pelos quais formulamos tais problemas.

Por exemplo, quando falo de coletivos, em vez de "sociedades", porque um coletivo é uma forma de agregação, de entidade que pode tomar for- 
mas as mais numerosas, dentre as quais a de sociedade. Quando parto do princípio de que existem tantas epistemologias quanto ontologias, ou seja, tantas teorias do sujeito, tantas teorias da açáo quanto maneiras de perceber continuidades e descontinuidades entre o humano e o náo humano, não coloco no primeiro plano ferramentas que costumeiramente empregamos para definir a realidade, ou seja, um ponto de vista epistemológico, com um sujeito etc.

Isso é, assim, um movimento de descentramento. Assim que a problemática ecoa a famosa observação de Wittgenstein: "se um leão falasse, não entenderíamos o que ele diz". É mais ou menos a mesma coisa, disto estou persuadido, e é nesse sentido que Eduardo e eu divergimos: eu diria que se um Jivaro fizesse antropologia, não entenderíamos o que ele diz.

Então sim, poderíamos fazer todo um esforço de tradução. Mas ele faria uma antropologia dele mesmo, e será que ele faria uma antropologia de nós? Sim, é evidente. Mas será que também faria uma antropologia dos australianos, dos chineses, dos gregos etc.? E como?

Tenho muita dificuldade em imaginar esse tipo de operaçáo. Posso entender a relação, a transposição, a extensão, diríamos, da relação de interlocução entre observador e observado e como afinal os Achuar têm muita coisa para dizer sobre mim e sobre nós, para o que eles daquilo conhecem etc. E isso é um campo extraordinariamente fecundo da antropologia atual. Mas como essa abordagem pode desenvolver-se além dessas situaçóes de interlocução? Isso não consigo vislumbrar bem. E, portanto, resolvi-me pelo fato de que a antropologia era a filha do naturalismo e que tudo o que podíamos fazer era limitar os estragos nos preconceitos eurocêntricos.

E de outra forma, Lévi-Strauss mesmo o dizia, aliás, num outro número de L'Homme sobre o parentesco, enquanto nossa geração tenta escapar à filosofia, agora ela volta a galope, mas não é mais a nossa filosofia, é a deles, mas vista através do olhar que nós temos daquela filosofia. ${ }^{3}$ É isso, acho, o debate, o problema mais importante atual, para mim em todo caso, na antropologia.

Aliás, é interessante porque há formas variadas de lidar com tal problema. Eduardo o faz da maneira mais interessante que há, quer dizer, com inventividade. Mas vejo outros antropólogos que o fazem de maneiras menos interessantes. Porque contentam-se em utilizar modelos alternativos que já estão presentes na filosofia ocidental. Daí o grande sucesso da fenomenologia, por exemplo. Merleau-Ponty dentre outros, porque é visto como um modelo alternativo em relação ao realismo cognitivo, em relação à teoria do sujeito etc. É como se, diríamos, os caçadores-coletores houvessem descoberto repentinamente a fenomenologia e houvessem, deste fato, empiricamente definido uma epistemologia que fosse muito mais adequada à apreensão do real, à apreensão do mundo ou à percepçáo do mundo, do que a analítica dos dualismos desenvolvida pelo naturalismo. Parece-me 
uma maneira pouco interessante de utilizar a filosofia. É, no fundo, imputar a populaçóes um tipo de presciência filosófica que, na verdade, é o resultado de uma longa história interna à filosofia ocidental.

O senhor comentou que se um Jivaro fizesse antropologia, seria interessante, primeiro ver o que é essa antropologia que ele está fazendo. Eu quero retornar a essa questão, mas antes quero colocar uma outra com relação às questôes ambientais mais atuais. Queria que o senhor comentasse o quanto Lévi-Strauss já antecipava, no final dos anos 1960, muitas questöes relacionadas às relaçôes entre homem e meio-ambiente muito antes dessa onda mais ambientalista, de uma perspectiva nativa dos amerindios.

PD: Não sei se é uma perspectiva ameríndia nele. Acho que está ligado primeiro à sua personalidade. Penso também que está ligado ao seu conhecimento do mundo e do pensamento extremo oriental. Ele conhece muito bem o Japão, o pensamento japonês, e também conhece muito bem o pensamento chinês, embora não o utilize tanto na sua obra. Acho que é uma combinaçấo de muitas coisas... É uma sensibilidade pessoal para a Natureza também. Teríamos que observar isso muito sistematicamente na sua obra. É muito difícil falar assim de Lévi-Strauss porque é uma obra imensa, muito multiforme, às vezes ele até diz coisas que são um pouco contraditórias, entáo teria que retomar tudo isso muito sistematicamente. Já se escreveu mais de uma centena de livros sobre Lévi-Strauss de modo que talvez algum nos escape sobre o sentimento da Natureza nele. Mas penso que os ameríndios são apenas um dos componentes da sua atitude frente à Natureza, que está também ligada a um pessimismo profundo e a alguma coisa, uma liçáo - a qual, acho, somos muitos que a retiveram - que é uma crítica ao antropocentrismo. É um pouco um paradoxo, quer dizer que agora somos muitos antropólogos a insistir sobre o fato de que a antropologia, se deve sobreviver, deve sair do seu antropocentrismo - para uma disciplina fundada sobre o antropos é um pouco paradoxal. Lévi-Strauss foi o primeiro a fazer isso, desantropocentrar a antropologia, e uma das consequências, ou das causas, disso foi a constataçáo dos estragos que o antropos fez nos outros patamares do Cosmos, nas relaçóes com outras entidades do mundo.

Para terminar, penso que o pensamento ameríndio é um dos elementos. Mas talvez outro elemento muito importante - disse-o, aliás - é o pensamento budista. Dizia que se devesse ser religioso, o que não era evidentemente, era provavelmente para o budismo que se viraria. Assim que são entrelaçamentos muito complexos, nos quais o pensamento ameríndio em relação aos não humanos é apenas um elemento. 
Eu queria fazer ainda uma ou duas questöes, para encerrar a entrevista. Com relação à ideia que o senhor mencionou, de como ver essa antropologia feita por indígenas, eu queria saber sua opinião sobre essa cada vez maior entrada de indígenas em cursos superiores, na universidade, e até mesmo em cursos de antropologia, e o que a gente pode prever, esperar, de uma antropologia feita...

PD: Não sei. Tem, na Europa, uma experiência desde já faz algum tempo, que é aquela dos colegas antropólogos africanos, incluindo, para alguns dentre eles, os que vieram fazer estudos etnográficos na França, por exemplo. E do que li, jamais fiquei surpreendido. Talvez seja devido a uma afinidade entre o que eu chamo de pensamento analogista europeu e o pensamento analogista africano, que tem elos importantes. Mas jamais fiquei surpreendido. Ou seja, jamais vi uma abordagem que fosse realmente muito diferente. Em contrapartida, fiquei realmente surpreendido por alguns antropólogos chineses. Pela maneira de abordar questôes muito bizarras, nem um pouco à maneira ocidental, a respeito do sujeito, do sistema de parentesco e de coisas assim. Entáo náo sei, espero para ver. Tenho receio de que, se tomamos o exemplo africano, o sistema de formação, de educaçáo no ensino superior termine por formatar a perspectiva dos antropólogos indígenas - é sempre a mesma questão do leão - e que percam uma parte da originalidade da perspectiva que podem ter sobre seu mundo e sobre nosso mundo. Espero para ver, com curiosidade, mas até agora para a experiência africana na Europa, em todo caso, não vi nada de surpreendente.

E isso pode projetar uma filosofia por vir? O Eduardo diz isso, que a antropologia lévi-straussiana projeta uma filosofia por vir e esse encontro talvez possa aquecer essa...

PD: Mas é que já tem uma filosofia. Para dizer as coisas com a maior simplicidade, penso que Claude Lévi-Strauss é um dos muito grandes pensadores do século XX, bem além da antropologia. Seu pensamento nos acompanhará por muito tempo ainda. Falava disso acima, há mais de cem livros que lhe foram consagrados, o que para mim é um sintoma importante.

E tem-se um movimento clássico de pêndulo e o que chamamos de pós-estruturalismo, o que não faz nenhum sentido, jamais entendi o que significava, mas enfim, um movimento em todo caso de reaçóes contra o estruturalismo. Todavia, como o estruturalismo náo era conhecido em países como a Inglaterra e os Estados Unidos, muito pouca gente de fato leu Lévi-Strauss nesses países, e menos ainda entenderam-no. Assim, teve um movimento de rechaço, o qual, exaltando a transparência na prática, a agency, as massas que fazem a história e a revoluçáo - coisas que bem conhecemos - decidiu que Lévi-Strauss deveria ser relegado à mera história. O que é interessante 
é que temos jovens pesquisadores brilhantes agora, anglófonos - não falo do Brasil, onde Lévi-Strauss é um personagem incontornável do pensamento -, nos Estados Unidos e na Inglaterra, que repentinamente voltam a ler Lévi-Strauss e a discuti-lo. Estamos assim na fase do pêndulo. No final, a minha geração e aquela do Eduardo fez um passo. Vamos continuar fazendo-o, é evidente, mas fomos atores diretos: eu conheci Lévi-Strauss, dirigi o laboratório que ele criou etc. O que é interessante agora é ver o que acontecerá numa segunda, numa terceira e numa quarta geração de gente que vai situar-se em relação a ele como frente a um maître à penser, um autor. Tal como Kant, ou Hegel, ou outros. E os resultados são imprevisíveis. Qualquer autor sabe que, a partir do momento no qual escreveu alguma coisa, os leitores apoderar-se-ão e faráo dela algo inteiramente diferente. Assim é o que acontecerá e acontece com Lévi-Strauss desde já há algum tempo e seguirá acontecendo. Mas esses efeitos podem ser, às vezes, muito interessantes. São efeitos de recepção, e isso é algo a ser observado.

Então, dentre os efeitos, tem aquele muito original do Eduardo, que é um tipo de pas-de-deux, entre o pensamento de Lévi-Strauss e aquele de Deleuze, ou um pas-de-trois, se se pode dizer, o que seria mais um tango ou uma valsa, entre o pensamento de Lévi-Strauss, o pensamento de Deleuze e o pensamento ameríndio. É uma combinação interessante, mas se tem numerosas outras.

No final, acho que sou muito pessimista quanto ao futuro da humanidade, como Lévi-Strauss o foi, mas sou bastante otimista quanto ao futuro do pensamento. O que é um pouco bizarro, porque poderíamos pensar que o pensamento permitiria trazer soluções aos desastres rumo aos quais a humanidade encaminha-se... Mas disso não estou seguro.

\section{Notas}

1. O filme pode ser assistido no seguinte site: http://www.vimeo.com/lisausp/ levi-strauss

2. Uma das revistas científicas mais antigas do mundo (1869), mais afim com os temas das ciências exatas e naturais.

3. N. de T.: "De ce courant d'idées, une impression d'ensemble se dégage : qu'on s'en réjouisse ou qu'on s'en inquiète, la philosophie occupe à nouveau le devant de la scène anthropologique. Non plus notre philosophie, dont ma génération avait demandé aux peuples exotiques de l'aider à se défaire ; mais, par un frappant retour des choses, la leur" (LÉVI-STRAUSS, 2000, p. 720). "Desta corrente de idéias, resulta uma impressão de conjunto: quer nos regozijemos, quer nos inquietemos, a filosofia está novamente no cen- 
tro do palco antropológico. Não mais a nossa filosofia, aquela de que minha geração queria se livrar com a ajuda dos povos exóticos; mas, em uma notável reviravolta, a deles.” (VIVEIROS DE CASTRO, 2001).

\section{Referências bibliográficas}

DESCOLA, Philippe; TAYLOR, Anne-Christine. Introduction. La remontée de l'Amazone. Anthropologie et histoire des sociétés amazoniennes. L'Homme, 126-128, p. 13-24. 1993.

LÉVI-STRAUSS, Claude. Contribution a l'étude d'organisation sociale des indiens bororo. Journal de la Société des Américanistes, t. 28, n. 2, p. 269-304. 1936.

. Les organisations dualistes existent-elles? In: Anthropologie structural. Paris: Plon, 1958.

. La geste d'Asdiwal. In: Anthropologie Structurale II. Paris: PLON, 1973. . Postface. L'Homme, 154-155. 2000.

VIVEIROS DE CASTRO, Eduardo. A propriedade do conceito. In: Seminário Temático, 23, 2001. Uma notável reviravolta: antropologia (brasileira) e filosofia (indígena). Anpocs.

entrevistador Edson Tosta Matarezio Filho

Formado em Ciências Sociais (USP). Mestre em Antropologia Social (USP), com dissertação sobre os índios Waimiri-Atroari. Doutor em Antropologia Social (USP), com pesquisa sobre a música, ritual, mitologia, organização social e parentesco dos índios Ticuna. É pesquisador do Centro de Estudos Ameríndios (CEstA-USP), do grupo de Pesquisas em Antropologia Musical (PAM-USP) e do Grupo de Antropologia Visual (GRAVI-USP). Atualmente desenvolve pesquisa de Pós-doutorado no Departamento de Antropologia da USP sobre a Festa da Moça Nova, o ritual de iniciação feminina dos Ticuna.

Recebido em 18/04/2015 Aceito para publicaçáo em 18/04/2015 